\title{
TERRITORIALIZANDO IDENTIDADES LUSÓFONAS: PERCURSOS DISCURSIVO-GRAMATICAIS
}

\author{
(Lusophone territorializing identities: \\ grammatical and discursive pathways) \\ Dina Maria Martins Ferreira ${ }^{1}$ \\ (Universidade Estadual do Ceará - UECE)
}

\begin{abstract}
This paper discusses the issue of lusophone identities, be it in its Brazilian or Portuguese usage. The texts for comparative analysis are in two levels: (1) the expression "never before" from Camonian literary discourse, XVI century, and from President Lula's political discourse, XXI century, in addition to (2) literary discourses, Azorean and Brazilian, which subsidize the lusophone communicative competence. The uninterrupted language route always brings to the surface residues from histories and identities by the discursive belonging or grammatical estrangements.
\end{abstract}

Keywords: identity, lusophony, belonging, estrangement.

\section{RESUMO}

Esse estudo discute a questão de identidades lusófonas, seja em seu uso brasileiro, seja em seu uso português. Os textos para análise comparativa se fazem em dois patamares: (1) expressão "nunca dantes" do discurso literário camoniano, século XVI, face a "nunca (d)antes" do discurso político do presidente Lula, século XXI; e (2) discursos literários, açoriano e brasileiro, que subsidiam a competência comunicativa de falantes lusófonos. O caminho ininterrupto da linguagem sempre traz à tona resíduos de histórias e identidades pelo pertencimento discursivo ou estranhamentos gramaticais. Palavras-chave: identidade, lusofonia, pertencimento, estranhamento.

1. Doutora pela UFRJ, $1^{\circ}$ Pós-doutorado pela Unicamp, $2^{\circ}$ pós-doutorado pela Université René Descartes, Paris V, Sorbonne. É membro efetivo do Centre d'Études sur les Actuels et le Quotidien/CEAQ, Sorbonne V, com atuação no Séminaire Franco-Brésilienne/SFB, e professora pesquisadora do Programa de Pós-Graduação em Linguística Aplicada da Universidade Estadual do Ceará/ UECE. 


\section{Encontro lusófono pelo ufanismo}

Vejo-me diante de uma reportagem do colunista Reinaldo Azevedo, conhecido como o 'cristo’2 do Presidente Luis Inácio Lula da Silva (mandatos 2002/2010). Esse colunista comenta sarcasticamente que os discursos de Lula, continuamente, em seu tom exaltador e messiânico, se não demagógico, apresenta em seus pronunciamentos a expressão "nunca antes (nesse país)", e algumas vezes "nunca dantes (nesse país"). Imediatamente o verso canônico de Camões, em Os Lusíadas, "mares nunca dantes navegados" vem ao pensamento. Tem-se aí uma questão sobre a identidade lusófona em sua prática discursiva: pergunta-se por que uma expressão como "nunca" (d) antes" sacralizada, em obra do século XVI, no território Portugal, ainda se repetia no século XXI, no Brasil, no mesmo tom de uma saga.

Não aventamos que o uso da expressão usada por Lula seja decorrente de conhecimento da literatura portuguesa camoniana, nem nos propomos a uma visão preconceituosa de comparação entre a estética literária clássica e o nível de escolaridade do Presidente $5^{\text {a }}$ série do ensino fundamental. Muitas outras justificativas podem ser levantadas para o tal uso: Lula ter ouvido essa expressão de seus membros ministeriais, tais como do Ministro da Cultura, e a ter reutilizado tendo em vista a percepção de seu tom ufanista; ser uma expressão ouvida durante a sua vida, mesmo sem noção de que teve um uso camoniano; ser resultado de um conhecimento enciclopédico; e simplesmente porque se apropriou da autoria da boca do povo. Seja qual for a justificativa do encontro de Camões com Lula, nenhuma delas se faz relevante para nosso estudo. Enfim,o que verificamos são épocas que se cruzam em lusofonia, tempo de séculos e terras diferentes na travessia de um rastro de identidade lusófona na prática discursiva.

2. Uma pessoa ser o 'cristo' do outro é uma gíria da língua portuguesa do Brasil, que indica ser uma pessoa tão ofensiva que se torna o motivo de grande sofrimento para o outro; faz o outro caminhar igual a Cristo, carregando uma cruz. Logo cruz pode ser considerado sinônimo de cristo pela equivalência de sentido a sofrimento. 
O referido colunista, Reinaldo Azevedo, em constante crítica à fala do presidente Lula, fornece dados quantitativos nos discursos presidenciais brasileiros: a expressão "nunca antes" teria em torno de 3000 ocorrências e a "nunca dantes”, 126. Muitas brincadeiras jocosas, muitas críticas ao tom ufânico dessa expressão, seja qual for sua variação de uso:

Mais cultura, 'menas' humildade

O presidente Luiz Inácio Lula da Silva disse ontem considerar repetitiva a expressão 'nunca antes neste país', que costuma preceder a enumeração de feitos do governo em seus discursos: 'Mas é verdade'. 'Está uma coisa tão repetitiva, [...] esse negócio de que 'pela primeira vez, 'nunca antes', 'nunca dantes' [...] (Jornal Folha de São Paulo, 9/1/09);

'nesse' país $[\ldots]$

É a expressão preferida do presidente do Brasil, na sua retórica demagógica.

Subjetivamente, porém, ao espezinhar a Gramática, no desconhecimento do emprego dos pronomes demonstrativos, Luiz Inácio demonstra, claramente, não saber onde está, afora não ver nada e não saber de nada. Não é 'nesse' país, Exmo. Sr. Presidente, mas, sim, 'neste' Brasil que gostaríamos de ver realizadas as maravilhas do seu discurso.

Por certo, na sua desorientação encontra-se a origem de tudo. A certeza é a de que V. Exa. refere-se a uma terra hipotética - a terra dos seus delírios -, que respira emanações de ebriedade coletiva. Neste Brasil, entretanto, não enxergo razões para muita euforia, ao menos enquanto países como Azerbaijão, Etiópia, Quênia, Zimbábue, Coreia do Norte, Cazaquistão, Cuba, e mais trinta outros merecem mais medalhas do que nós (Paulo Carvalho Espíndola, TERNUMA Regional Brasília);

Não deixe de votar, divulgue entre os seus amigos; nunca se sabe quando [...] não menos importante, o uso indiscriminado dos Cartões Corporativos. (...) rios 'nunca dantes' bundeados, [...] e 'nunca antes' pagamos tantas taxas bancárias: é o bolsa-família dos banqueiros [...] (www.veja.com).

Apesar de tantas ironias a respeito do uso dessas expressões pelo presidente, nosso objetivo não é nem questionar o certo e errado sob a perspectiva gramatical de seu uso em relação às normas da língua 
portuguesa. A questão é nos perguntar como essa prática discursiva chegou até nós, do século XVI ao XXI, tendo em vista a manutenção e intenção de louvar e aplaudir uma pátria, seja em uma epopeia literária, seja na demagogia do discurso político brasileiro.

\subsection{Caminho bustrofédico da linguagem}

O primeiro degrau de nossa argumentação é ler o jogo designativo "nunca dantes" e "nunca antes" a partir da ideia de que a língua é ecológica. Entende-se que a linguagem tem em sua natureza a capacidade de ressignificar a cada momento de sua materialização em língua, uma vez que a linguagem não exclui significações ao longo de seu percurso no espaço-tempo histórico; ao contrário, a cada expressão significante, resíduos significativos se processam e se remodalizam.

E é pelo movimento da escritura ${ }^{3}$ (Derrida, 1999: 351-352) que se postula ter a linguagem natureza ecológica:

Trata-se da escritura por sulcos. O sulco é a linha, tal como a traça o lavrador: a rota - via rupta - cortada pela relha do arado. O sulco da agricultura, também o recordamos, abre a natureza à cultura. E sabese também que a escritura nasce com a agricultura, que não se dá sem a sedentarização.

Ora, como procede o lavrador? Economicamente. Chegando ao fim do sulco, ele não volta ao ponto de partida. Dá meia volta ao arado e ao boi. Depois, parte novamente, em sentido inverso. Poupança de tempo. De espaço e de energia. Melhoria do rendimento e diminuição do tempo de trabalho. A escritura de volta de boi - bustrofédon - [...] .

Derrida pleiteia um movimento bustrofédico, isto é, um movimento contínuo, da esquerda para direita e da direita para a esquerda, como o arado do boi sulcando a terra. Sob a ótica bustrofédica

3. O termo "escritura", sob a égide da filosofia derridiana, não se vincula apenas à escrita, mas também à phone, tendo em vista o conceito de arquiescritura, ou seja, a linguagem que antecede a fala e a escrita (Derrida, 1999). 
da linguagem, verifica-se que nesse movimento não há interrupção, cuja continuidade permite reafirmar que a linguagem é ecológica, isto é, processo de contínuo re-aproveitamento da terra-linguagem em que o vaivém desvela o ontem e o hoje. Se o processo de cultivo é contínuo, a cada plantio linguageiro resíduos remanescentes de uma antiga plantação revolvem-se para se agregar à próxima; a terra na qual as designações são plantadas não consegue eliminar e substituir os rastros de antigas plantações; é no revolver da linguagem-terra que novos grãos designativos se encontram com resíduos de outros grãos remodalizando-se em novos jogos de linguagem. Um momento histórico da linguagem não elimina o anterior e nem se exclui do posterior.

E por esse raciocínio já se pode reconhecer o sentido discursivo de "nunca dantes" do XVI atuando no uso de "nunca dantes" e "nunca antes" do século XXI.

\subsection{Jogos de sentido}

As expressões "nunca dantes" ou "nunca antes", tanto no caso de "mares nunca dantes navegados", quanto no de "nunca (d)antes nesse país", semanticamente, trabalham em dois patamares: o da ação e o do tempo. No quesito ação, a negação "nunca" elimina a realização da ação presente ou passada ou futura. É o caso das sentenças - nunca navego, nunca naveguei, nunca navegarei, nunca navegadas -, que elimina a possibilidade de realização da ação de navegar, ou seja, a ação de navegar é impedida de se realizar. No quesito tempo, a marca "antes", à primeira vista, apenas indicaria um tempo passado, anterior ao presente. Mas, ao se aliar sintático-semanticamente ao "nunca", reforça a eliminação da ação, no caso a ação passada. Ao excluir qualquer ação do passado, hiperboliza-se a ação ufanista do presente e seus louros futuros. Se os mares nunca foram navegados, a navegação presente ou futura clama por ação, e se nunca antes nesse país nada se fez, a ação presente é forte com maravilhas de futuro.

Nesse jogo de sentido, pontua-se, então, pela exclusão da ação passada, pela presença da ação do presente e pela promessa de ação futura, o colorido ufânico das terras louvadas - Portugal e Brasil. 
Ratificando a ecologia da linguagem e seu percurso bustrofédico, chegamos ao encontro simbólico do ufanismo de momentos históricos diferentes. Cada cultura em seus momentos de uso linguístico é uma queda em história, e como tal está circunscrita a um tempo e um espaço próprios. O que se está propondo é a percepção de que

os símbolos são diversamente vividos e valorizados: o produto dessas múltiplas atualizações constitui em grande parte os 'estilos culturais' (..) (e) como formações históricas, essas culturas não são mais intercambiáveis; estando já constituídas em seus próprios estilos, elas podem ser comparadas no nivel das imagens e dos símbolos (Eliade, 1996: 173) (ênfase acrescida).

O contato discursivo de uma 'mesma' língua em momentos culturais e históricos diferentes seria possível por seu caráter ecológico que espalha resíduos de significação na estrada bustrofédica da linguagem. O toque entre usos gramaticais e sentidos discursivos se dá pelos resíduos do caminho ininterrupto, até porque símbolos são convenções muito fortes, cristalizações sociais, signos difíceis de se desmantelarem no cansaço do percurso histórico. O símbolo do ufanismo até hoje se estabelece em várias pátrias, haja vista as guerras que se estabelecem pela luta de pertença e de manutenção de sua história. Por que então, tendo à disposição uma expressão sacralizada desse símbolo no universo lusófono, ela não seria reaproveitada e reutilizada para fins políticos?

A noção de símbolo pode ser entendida pelas propriedades de duração e equivalência. Na questão da durabilidade de sentido, símbolo são resíduos de significação que se fazem duráveis ao longo das araduras da linguagem, uma vez que significações de vida cultural não são trituradas e dissolvidas imediatamente à passagem do arado do boi; são resíduos duráveis de significação cujas marcas profundas de expansões significativas são 'relembradas' em significantes adequados a seu contexto histórico; é nesse 'relembrar' do universo simbólico que é possível perceber o contato entre discursos históricos de uma mesma língua. E no teor da equivalência, a própria etimologia do termo 
símbolo reforça tal atributo - em grego, sýmbolon (de syn, junto, e ballein, atirar, lançar):

'lançar com', arremessar ao mesmo tempo, 'com-jogar'. De início, símbolo era um sinal de reconhecimento: um objeto dividido em duas partes, cujo ajuste, confronto, permitia aos portadores de cada uma das partes se reconhecerem. O símbolo é, pois, a expressão de um conceito de equivalência." (Brandão, 1986: 38) (ênfase acrescida).

Ao se permitir a equivalências de significado, o símbolo, vivendo nos sulcos da linguagem, não se imobiliza no tempo e espaço em que se manifesta. Sua natureza estável mais a de "com-jogar" significações em marcha bustrofédica permitem que caminhem em direção a outras histórias sem anular as anteriores, refazendo em sua contínua aradura discursiva outros modos de existência.

A natureza do símbolo, caracterizada pelos traços de durabilidade e equivalência de significações, justifica a repetição de usos linguísticos que se expandem no trans-histórico. Não há ponto de saturação na reticulação significativa, nem mesmo na simbólica, uma vez que "é situada e sensível a fatores contingentes de coordenadas espáciotemporais que marcam sua produção [...] É dispersão e disseminação em um interminável processo" (Rajagopalan, mimeo: 3).

\section{Desencontro na lusofonia}

Enquanto pôde-se atestar o encontro discursivo-gramatical de momentos diferentes - séculos XVI e XXI - e de gêneros discursivos considerados incompatíveis - literatura e discurso político -, ou seja, pontos que mesmo na linearidade da diacronia de língua se sobrepõem, este encontro pode se tornar desencontro, e mais ironicamente ainda, por se tratar de um desencontro na linha sincrônica da língua. Ou seja, tendo em mãos dois discursos literários, um açoriano e outro brasileiro, ao que se chamaria de escritura lusófona - todos pertencentes ao mesmo cesto linguístico - manifestam-se divergências discursivogramaticais. 
Para a referida argumentação dois textos literários fazem o papel de referência cultural de um povo, de um território, de um grupo: "Cães Letrados", de Cristóvão de Aguiar (2008), da literatura açoriana, e "Cego e amigo Gedeão à beira da estrada", de Moacyr Scliar (1994), da literatura brasileira. Por esses textos verificam-se estranhamentos e reconhecimentos discursivos, pertinentes a diferença de território e de cultura. Para justificar os olhares, utilizamo-nos do Dicionário Priberam da Língua Portuguesa (2008, serial) e o Dicionário Houaiss da Língua Portuguesa (2009); o primeiro especificando a lusofonia portuguesa e consequente estranhamento ao uso brasileiro, e o segundo, para justificar as especificidades reconhecidas como pertencentes à cultura brasileira.

\subsection{Cultura nacional: territorialização e historialidade}

Acreditamos que cultural nacional se estabelece por histórias (propositadamente com letra minúscula) para a constituição da História de uma nação. Já História com letra maiúscula corresponderia às várias histórias que se unem, passando aquela a ter o valor de verdade única, cujo entrelaçamento dos tempos presente, passado e futuro narrativizam uma História que reflete uma "comunidade imaginada" (Hall, 2000). Para fundamentar o caminho de uma História formadora de uma "comunidade imaginada", alguns pontos são reveladores:

a) trata-se de narrativa "tal como é contada e recontada nas histórias e nas literaturas nacionais, na mídia e na cultura popular" (Hall, 2000: 52);

b) são narrativas que dão "ênfase nas origens, na continuidade, na tradição e na intemporalidade” (ibidem: 53);

c) inventa-se uma tradição, que, segundo Hobsbawn e Ranger (apud Hall 2000: 54), seria um “conjunto de práticas, de natureza real ou simbólica, que buscam inculcar certos valores e normas de comportamentos de repetição, a qual, automaticamente, implica continuidade com um passado histórico adequado”. 
Esses elementos apresentados por Stuart Hall discutem o conceito de cultura nacional não como um conjunto unitário, o que faz com que a nomeação das culturas açoriana e brasileira seja um corte epistemológico, nem puro, nem de valores atemporais. Como os próprios discursos literários indicam, os autores são situados em tempos e espaços diferentes, com percursos coletivos e individuais próprios, constituindo, assim, a noção de cultura como uma construção discursiva, permeada de contingência e história. Logo o que se chama de "comunidade imaginada" é um 'lugar' de histórias contadas e recontadas, influenciada pelos contadores e pelas próprias histórias que a constitui; histórias baseadas em mitos, deixando de lado os movimentos e deslocamentos que ocorrem ao longo do que se chama História. Bhabha (1998: 238-239) nos lembra que as contingências históricas seriam os fundamentos da necessidade de elaborar estratégias legitimizadoras de "minorias dentro das divisões geopolíticas", minorias aqui entendidas como comunidades em busca de seu perfil identitário.

O que realmente podemos entender como cultura revelada por discursos é a rearticulação de signos que inscrevem identidades culturais. Segundo Bhabha (1998:240), cultura "é a marca do espaço conflituoso mas produtivo, no qual a arbitrariedade do signo de significação cultural emerge no interior das fronteiras reguladoras do discurso social”. Desse modo, a ideia de cultura iria para além de uma noção canonizada de estética para uma visão de cultura de "produção irregular e incompleta de sentido e valor, frequentemente composta de demandas e práticas incomensuráveis, produzidas no ato da sobrevivência social” (ibidem).

Junto ao sentido de cultura, alia-se o de território. Haesbaert (2006) nos oferece vários caminhos, mas já que estamos no universo de uma "comunidade imaginada", nada mais coerente do que tratar território pela vertente cultural ou "simbólico-cultural: [que] prioriza a dimensão simbólica e mais subjetiva, em que o território é visto, sobretudo, como o produto da apropriação/valorização simbólica de um grupo em relação ao seu espaço vivido" (Haesbaert 2006: 40). Ou seja, a dimensão simbólica habita um espaço social organizando- 
se pela historicidade e geograficidade, quesitos constitutivos de territorialidade.

E uma teia identitária se organiza a partir da culturalidade e da territorialização, embrenhada na História, que por sua vez nos mostra outros caminhos: historicidade e historialidade. Historicidade estaria para a ideia de motivo, na medida em que "nasce da autoapreensão do homem em relação ao vivente e à vida (Derrida, 2002: 49-50), ou melhor, como o habitante de determinado território se motiva na história da qual participa e nas relações que estabelece em sua comunidade. Historialidade seria o efeito identitário da narrativa histórica porque provoca e acolhe a posição de pertença - pertença a um grupo, a uma nação, a um povo. A história seria então "um processo objetivo no qual estamos inseridos [...] um modo de estarmos conscientes dessa pertença (Vattimo, s/d:11). Historialidade e historicidade se movimentam em direções diferentes, ao mesmo tempo que se constituem simbioticamente. A historicidade, o motivo de estar em determinada história, explode para que outra narrativa histórica se inicie; já o movimento da pertença é efeito da história que faz com que os sujeitos implodam, imergindo na história. Enquanto o motivo atua no instante de um momento histórico, a pertença é um movimento mais denso, pois trabalha com símbolos socioculturais. Pertença aciona a tradição, reconstruída ou não, pois se alimenta de símbolos que se performatizam pela memória. Sem motivo não há história e só há pertença se houver história. Ambos trabalham na reivindicação da identidade. Esses tantos movimentos de/em histórias perfilam a complexidade identitária, já que mudanças do tempo passado, presente e futuro, mais deslocamentos de dados, revelam os "distúrbio(s) de direção" identitários (Bhabha, 1998:19).

\subsection{Reconhecimento}

E diante das prerrogativas do que entendemos por cultura nacional, o reconhecimento de território e, por conseguinte, o de pertença, o discurso de Moacyr Scliar (anexo) nos propicia 
o reconhecimento de brasilidade. Os atributos escolhidos para o reconhecimento de brasilidade são os da intensidade e da informalidade discursivas, propriedades validadas não só pela justificativa discursiva, mas também pelo senso comum.

O uso de diminutivos é geralmente utilizado para indicar uma certa proximidade, intimidade ou afeto aos elementos nominalizados que sofrem tal determinação: "caminhão Mercedinho"; "Gosto mais da noite: é fresquinha, nesta época”. Em ambos os exemplos, reconhecese a brasilidade: primeiro, por meio da intimidade e importância que brasileiros dão a carros; e, segundo, pelo diminutivo que é empregado no sentido de conforto/prazer em relação ao clima.

Geralmente, no português do Brasil, o diminutivo é usado profusamente com o sufixo -inho/a. Além do jogo afetivo, o diminutivo pode ser empregado em sentido pejorativo, indicando desprezo, desqualificação ou rebaixamento, como por exemplo "mulherzinha" que quer dizer mulher desqualificada. Mas mesmo assim, não importa qual a direção qualificadora, sempre a emoção está presente.

Nesse jogo do uso do grau, o afetivo também se instala no aumentativo, já que enaltece e aumenta o valor do que é nomeado. Por exemplo, "um amigão" quer dizer um amigo muito próximo ou muito confiável; o que se aumenta é a proximidade a essa pessoa e não o tamanho físico da pessoa indicada como amigo. $\mathrm{O}$ aumentativo na língua portuguesa brasileira é muito usado pela derivação com sufixo -ão/ona, tal como "meninona" como forma de engrandecer a menina a qual se refere, ou seja, uma menina especial.

Como estamos tratando de usos, e usos linguísticos se manifestam em territórios com suas histórias, contadas e recontadas pelo conto popular, pela mídia etc., não se pode esquecer que muitas combinações lexicais resultam de condicionamentos às histórias que nos rodeiam e que constroem símbolos culturais. No emprego do sufixo -aço - "Um fazendeiro muito rico. Mataram com quinze balaços" -, "balaços" não indica necessariamente apenas o poder material da bala que mata, nem a bala de um super atirador com mira certeira. Construções nominalizadoras também são resultado das histórias em que o léxico se instala. Este "balaço" ocorreu em território brasileiro, 
onde a violência, mesmo que intensificada pelas notícias midiáticas, é conhecida como parte do identitário brasileiro. O uso do léxico "balaço" não justifica histórias contadas que vão construir a realidade da violência brasileira? Não seria fruto de narrativas que inventam uma tradição de violência? Não seria essa invenção de tradição um "conjunto de práticas, de natureza real ou simbólica, que buscam inculcar certos valores e normas de comportamentos de repetição, a qual, automaticamente, implica continuidade com um passado histórico adequado” (Hobsbawn e Ranger apud Hall 2000: 54)? A historialidade e a historicidade ecoam no sentimento de pertença a uma terra violenta.

Junto a sufixos diminutivos e aumentativos, outros recursos de qualificação afetiva ocorrem, tal como, "grande caminhão", não só um objeto de vultuosas medidas, mas também um objeto de qualidade, cujas valorações de tamanho e qualidade dão ao objeto "caminhão" a propriedade de algo próximo e familiar ao cotidiano de seu proprietário. Na calçada da rua, ou seja, no uso corriqueiro, não há como negar, por exemplo, que até o diminutivo se torna base estilística de aumentativo para alcançar mais intensidade, por exemplo, - Nossa! Olha a roupa dela! Deve ter dinheiro! Está 'pobrinha' de chique. E nesse 'pobrinha', não há como negar a intensidade que habita o construto identitário do brasileiro

Outras adjetivações também reforçam esse perfilamento da intensidade brasileira, tais como a proximidade dos brasileiros a carros: "Simca Tufão”, "Gordini Teimoso", "Chevrolet Pavão”, "Volkswagen 1962”, "caminhão Mercedinho", "Ford 1956", “Oldsmobile 1927”, "Volkswagen 1964”, "DKW”, "Galaxie”, "Aero Willys”, "Candango”, "Toyota". Segundo pesquisas, nomenclaturas dadas aos carros, tais como Tufão, Teimoso, Pavão, Candango etc., são apelidos populares que eram utilizados tanto pelos usuários/consumidores de carros quanto pelas próprias fábricas da época; enfim, um jogo relacional que reforça a intimidade dos brasileiros a carros, tanto que lhes são atribuindo propriedades de seres animados.

Não estariam aí atributos perfiladores da cultura da intensidade e informalidade brasileira? Ou seja, não está aqui retratada a 
capacidade de teatralizar e intensificar sentidos? Pelo senso comum ou pelo folclore turístico, dizem que estar em uma excursão brasileira é ouvir gritos, cantos, entusiasmo: - Olhem, ali, com essa falação, toda só podem ser brasileiros.

\subsection{Estranhamento}

No universo do estranhamento, o lusófano brasileiro reluta diante do uso de alguns léxicos usados em territórios outros, também ditos lusófonos. O texto de Cristóvão de Aguiar (anexo) não é, obviamente, medido pela 'estrangeiridade', pois não negamos a 'unidade' interlocucionária lusófona. $\mathrm{O}$ estranhamento é o de não pertencimento a um território com suas simbologias e histórias, retratado pelo uso linguístico.

Ao entrar em contato com o verbo "tressuar", nos obrigamos a ir ao dicionário para reconhecer seu sentido mais objetivo. O leitor brasileiro começa ao buscar a sua relação com o verbo "suar". Mas não é suficiente. Houaiss nos avisa ser um léxico do século XVII (1614), "três + suar". O brasileiro acessa o sentido de "suar copiosamente" e "verter (líquido) como se fosse suor, transudar, expelir" (Ex: tressuava sangue). Já DPLP apenas indica "suar muito". No uso cotidiano, o lusófono brasileiro não faria a ligação de "três-" com o intensificador "muito" ou "copiosamente". Usaria, com certeza, "suar muito" ou "pingar" - "Estou pingando de calor".

Em um segundo exemplo - "está a beirar seus meses de vaidade, cachorra de raça pura, brincalhona, estreloiçada, toleirona" -, dois estranhamentos se processam: "beirar" e "estreloiçada". Embora o Dicionário Houaiss, em uma de suas definições, especifique o sentido de "beirar" como "contar aproximadamente" e "aproximar-se", não é usual a utilização de tal vocábulo para expressão de tempo. Seu uso está para um contexto de posição: "deslocar-se à beira de; ir pela margem de; costear, ladear, margear (Ex.: corre a jangada, beirando os recifes); fazer limite (com), confinar (com) (Ex.: a lagoa beira (com) o nosso quintal); contar aproximadamente; abeirar-se de (Ex.: ela já 
está beirando (pel)os 30 anos); estar a ponto de atingir; aproximar-se de (Ex.: isso beira o desrespeito). Além do uso do sentido de "beirar", não poderíamos deixar de lado o que até se tornou um jogo folclórico em torno de piadas de brasileiros imitando o português: infinitivo precedido de preposição "a”, em contrapartida ao gerúndio: "a beirar" vs. "beirando", respectivamente.

No vocábulo "estreloiçada", o primeiro ponto de estranhamento seria em relação ao uso do ditongo "oi”. Um falante nativo brasileiro imediatamente buscaria pelo ditongo -ou. Mesmo trocando os ditongos - "estrelouçada" -, o estranhamento continua, pois o brasileiro perguntaria se em vez de "louça" não seria "louca". O DPLP nos apresenta "estrelouçada" significando "barulho de louça de quebrando". Como poderia ser "louça" se estamos falando de um cão barulhento? E o estranhamento se torna um zigue-zague de brincadeiras - "tresloucada" ou "tresloiçada" ou "tresloucada" ou "tresloicada"? Mas o lusófono brasileiro ficaria com "tresloucada" para chegar ao sentido de "cachorra barulhenta".

\section{Reencontro $\mathrm{da} / \mathrm{na}$ lusofonia transnacional}

Mas não pode se evitar o reencontro lusófono. Para Bhaba, cultura é fenômeno transnacional, já que os discursos contemporâneos estão enraizados em histórias específicas de deslocamento cultural. Talvez aqui se explique a lusofonia como uma unidade transnacional que apresenta particularidades territoriais em seu uso:

Torna-se crucial distinguir entre a semelhança e a similitude dos símbolos através de experiências culturais diversas - a literatura, a arte, o ritual musical, a vida, a morte - e da especificidade social de cada uma dessas produções de sentido em sua circulação como signos dentro de locais contextuais e sistemas de valor específicos. [...] O discurso natural(izado), unificador, da 'nação', dos 'povos' ou da tradução 'popular' autêntica, esses mitos incrustados da particularidade da cultura, não pode ter referências imediatas. A grande, embora desestabilizadora, vantagem dessa posição é que ela 
nos torna progressivamente conscientes da construção da cultura e da invenção da tradição (Bhabha 1998: 241).

No encontro lusófono de Lula com Camões há talvez o oferecimento de uma "pátria imaginada” (Rushdie ,1991: 9)? A pátria do sebastianismo? A pátria brasileira? Rushdie ao mirar no espelho sua pátria Índia apenas recolhe em sua memória "vidros quebrados" que chegam ao presente. Lula, ao usar "nunca dantes", não estaria recolhendo vidros quebrados? A forma pode ser a mesma, mas a simbologia do ufanismo é alimentada diferentemente. Lula não recolhe o "espelho da nostalgia”, mas simplesmente mostra que o uso de uma mesma forma gramatical lusófona tem resíduos de significação, mas com políticas de representação diferentes. É justamente "na natureza parcial dessas memórias que suas fragmentações são evocadas, [adquirindo] status e ressonância justamente por causa de sua permanência” no presente (Rushdie, 1991: 12). São as fragmentações de historicidades que fazem com que "coisas triviais uiram o status de símbolos, com até qualidades numenais"4 (Rushdie, 1991: 12). Rastros de um passado - "mares nunca dantes navegados -, se fazem presentes - "nunca (d)antes nesse país” -, mas sempre ressignificados. Como diz Charles Taylor (apud Appiah, 2005: 128), "como indivíduos nós valoramos determinadas coisas, encontramos certos complementos bons, certas experiências satisfatórias, certos prognósticos positivos. Mas certas coisas podem ser boas em determinados meios ou satisfazer suas formas particulares, porque o conhecimento do passado se desenvolve em nossa cultura”.

Mesmo que pensemos que a continuidade e uso de "nunca dantes" signifique "formação de práticas, instituições e compreensão de sentido às nossas ações - um local de utilidades -, suas naturezas não outorgam que tais utilidades sejam sociais" (Appiah, 2005: 128), ou seja, determinado fragmento do passado não necessariamente transita no universo ufanista, apenas reside em um mundo imaginário, alimentando a construção de uma "pátria imaginada".

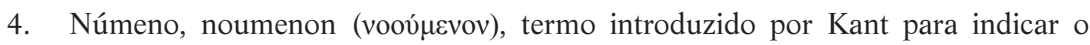
objeto do conhecimento intelectual puro, que é a coisa em si. 
No percurso do reconhecimento identitário, o lusófono brasileiro comum atinge a cultura brasileira pela intensidade e simbologias próprias. E no seu estranhamento, procura reconhecer seu território, e como não o acha, sua identidade fica diluída: diluída pelo estranhamento e construída pelo reconhecimento da possibilidade de interação lusófona. O que salientamos é que o critério de reconhecimento e de estranhamento, na questão de identidade e cultura nacional, é balizado pela pertença a um território, que se constrói pelas práticas discursivas e que, sem dúvida, pode atingir a uma identidade transnacional.

\section{Considerações finais}

Do encontro entre Camões e Lula, reconhecemos a ecologia da linguagem, do desencontro entre Cristóvão de Aguiar e Moacyr Scliar culturas e territórios clamam por sua identidade. E do reencontro, a unidade de diferenças se manifesta. Reconhecimentos e estranhamentos são da ordem da territorialização, que nos dão especificidades identitárias de uma cultura nacional. Mas mesmo assim, a identidade transnacional linguística ainda nos agrega pela interlocução entre discurso e gramática, cujas fronteiras se diluem pelo clamor de uma unidade transnacional. Sem dúvida, o contruto identitário está em linguagem, seja pela prática discursiva que se assemelha, seja por estranhamentos gramaticais. De qualquer forma há o pertencimento ao discurso lusófono que se estrangeiriza por estranhamentos gramaticais. De toda forma a reivindicação identitária se constitui, seja portuguesa, seja brasileira.

\section{Referências bibliográficas}

Aguiar, C. de. Cães Letrados. Portugal: Calendário, 2008.

Appiah, K. A. The ethics of identity. United Kindom: Princenton University Press, 2005. 
Bhabha, H. O local da cultura. (Trad. Myriam Ávila). Belo Horizonte: Editora UFMG, 1998.

Brandão, J. de S. Mitologia Grega. Vol. I. Rio de Janeiro/Petrópolis: Vozes, 1986.

Derrida. J. O animal que logo sou. (Trad. Fabio Landa). São Paulo: Editora UNESP, 2002.

. Gramatologia. 2a . ed. (Trad. Renato Janine Ribeiro) .São Paulo: Editora Perspectiva, 1999.

Dicionário Priberam da Língua Portuguesa (DPLP. Disponível em: http:// www.priberam.pt/DLPO/, 2008; último acesso julho de 2010.

Eliade, M. Imagens e Símbolos. Ensaio sobre o simbolismo mágico-religioso. (Trad. Rogério Fernandes) São Paulo: Martins Fontes, 1996.

Haesbaert, R. O mito da desterritorialização. Do 'fim dos territórios' a multiterritorialidade. São Paulo: Bertrand Brasil, 2006.

Hall, S. A identidade cultural na pós-modernidade. (Trad. Tomaz Tadeu da Silva e Guacira Lopes Louro). Rio de Janeiro: DP\&A, 2000.

Houaiss, A. Dicionário Houaiss . Rio de Janeiro: Objetiva, 2009.

Rajagopalan, $\mathrm{K}$. The world as a stage magic realism and the politics of representation, mimeo, $\mathrm{s} / \mathrm{d}$.

Rudshie, S. Imaginary Homelands-essays and criticism 1981-1991. London: Penguin Books, 1991.

Vattimo, G. O fim da Modernidade - Niilismo e Hermenêutica na Cultura Pós-moderna. (Trad. Maria de Fátima Boavida). Lisboa: Presença, s/d.

Recebido em: julho de 2010 Aprovado em: setembro de 2010 dinaferreira@terra.com.br 


\section{Anexo 1}

Aguiar, Cristóvão de. Marcha Estugada In: Cães Letrados. Portugal: Calendário, 2008.

Saí logo de manhã, marcha estugada, nervosa, é dia de ser homenageado Deus me acuda!

$\mathrm{Na}$ freguesia havia um homem, o Ti Barriga, cavaleiro assíduo das Cavalhadas em honra de S. Pedro da Ribeira Seca. Nunca acertava com a pronúncia da palavra. Cabia-lhe o papel de se dirigir ao santo e despejar-lhe uma réstia de quintilhas laudatórias. $\mathrm{O}$ ensaiador bem que suava: nunca se consolou que ele a articulasse com correcção, dizia sempre: "Ó homijado Chaveiro do Céu”...

O passeio acelerado converter-se-á em corrida em direcção não se sabe de que meta, ou talvez se saiba, mas quem ousa enunciá-la? Inominável como o Deus da Bíblia e do Alcorão.

Mal empregado o vento que faz dançar a chuva. Passei a manhã, ainda noite escura, mais ou menos ao derredor de mim e da casa. Com a mudança da hora no fim do mês, será já manhã clara, hora de Inverno, mais vizinha da solar e mais conforme com o ritmo biológico.

O exercício custa tanto ou mais do que lá em cima, na Mata do Rei, tressuei na mesma a subir e a descer ladeiras íngremes, a vida é uma das mais alcantiladas, grande pena já não haver, em Vale de Canas, árvores alegrando e oxigenando o percurso.

Estive lá há dias e fiquei com o coração tão negro como o que delas sobrou do incêndio - tições esmorecidos. Apesar do fresquinho matinal, cheguei a casa encharcado de chuva e suor.

Antes queria ir a casa do meu amigo para matar saudades da Tina, ando sôfrego por vê-la: já deve parecer uma senhorita. Não admira. Está a beirar seis meses de vaidade, cachorra de raça pura, brincalhona, estreloiçada, toleirona. Há quem prefira os sem pergaminhos e sem pedigree, humildes, quase sempre mais carinhosos e afeiçoados a quem lhes dá pão e abrigo.

Imagine-se como não devem estar os onze filhotes da Pipa, muito falidinhos mas encanadores. Não surpreende, filhos de cadela livre, sem preconceitos, medo não teve de, numa hora para outra, encher a casota de descendência, alheia ao que o Tribunal Constitucional resolvera acerca do 
referendo sobre a interrupção voluntárao da gravidez - louvada seja tanta fertilidade, só mesmo com o concurso de três progenitores, todos pais legítimos (assim poderá acontecer com a canzoada) e decerto babadinhos da sua paternidade sem sombra de ciúme uns dos outros...

Só desta maneira poderia a Pipa pôr no mundo prole tão numerosa, demais a mais num universo tão excessivo como o da Ilha, por onde até há pouco andei peregrinando com todos os meus botões bem caseados!

\section{Anexo 2}

Scliar, Moacyr. Cego e amigo Gedeão à beira da estrada. In: Para Gostar de Ler,Contos. Volume 9. São Paulo: Ática, 1984.

- Este que passou agora foi um Volkswagen1962, não é, amigo Gedeão? - Não, Cego. Foi um Simca Tufão. — Um Simca Tufão? ... Ah, sim, é verdade. Um Simca potente. E muito econômico. Conheço o Simca Tufão de longe. Conheço qualquer carro pelo barulho da máquina. Este que passou agora não foi um Ford? — Não, Cego. Foi um caminhão Mercedinho.

— Um caminhão Mercedinho! Quem diria! Faz tempo que não passa por aqui um caminhão Mercedinho. Grande caminhão. Forte. Estável nas curvas. Conheço o Mercedinho de longe... Conheço qualquer carro. Sabe há quanto tempo sento à beira desta estrada ouvindo os motores, amigo Gedeão? Doze anos, amigo Gedeão. Doze anos. É um bocado de tempo, não é, amigo Gedeão? Deu para aprender muita coisa. A respeito de carros, digo. Este que passou não foi um Gordini Teimoso?

- Não, Cego. Foi uma lambreta. - Uma lambreta... Enganam a gente, estas lambretas. Principalmente quando eles deixam a descarga aberta. Mas como eu ia dizendo, se há coisa que eu sei fazer é reconhecer automóvel pelo barulho do motor. Também, não é para menos: anos e anos ouvindo!Esta habilidade de muito me valeu, em certa ocasião... Este que passou não foi um Mercedinho? - Não, Cego. Foi o ônibus. - Eu sabia: nunca passam dois Mercedinhos seguidos. Disse só pra chatear. Mas onde é que eu estava? Ah, sim.Minha habilidade já me foi útil. Quer que eu conte, amigo Gedeão? Pois então conto. Ajuda a matar o tempo, não é? Assim o dia termina mais ligeiro. Gosto mais da noite: é fresquinha, nesta época. Mas como eu ia 
dizendo: há uns anos atrás mataram um homem a uns dois quilômetros daqui. Um fazendeiro muito rico. Mataram com quinze balaços. Este que passou não foi um Galaxie?

— Não. Foi um Volkswagen 1964. — Ah, um Volkswagen... Bom carro. Muito econômico. E a caixa de mudanças muito boa. Mas, então, mataram o fazendeiro. Não ouviu falar? Foi um caso muito rumoroso. quinze balaços! E levaram todo o dinheiro do fazendeiro. Eu, que naquela época já costumava ficar sentado aqui à beira da estrada, ouvi falar no crime, que tinha sido cometido num domingo. Na sexta-feira, o rádio dizia que a polícia nem sabia por onde começar. Este que passou não foi um Candango? - Não, Cego, não foi um Candango. - Eu estava certo que era um Candango... Como eu ia contando: na sexta, nem sabiam por onde começar. Eu ficava sentado aqui, nesta mesma cadeira, pensando, pensando... A gente pensa muito. De modos que fui formando um raciocínio. E achei que devia ajudar a polícia. Pedi ao meu vizinho para avisar ao delegado que eu tinha uma comunicação a fazer. Mas este agora foi um Candango! - Não, Cego. Foi um Gordini Teimoso. - Eu seria capaz de jurar que era um Candango. O delegado demorou a falar comigo. De certo pensou: "Um cego? O que pode ter visto um cego?" Estas bobagens, sabe como é, amigo Gedeão. Mesmo assim, apareceu, porque estavam tão atrapalhados que iriam até falar com uma pedra. Veio o delegado e sentou bem aí onde estás, amigo Gedeão. Este agora foi o ônibus? - Não, Cego. Foi uma camioneta Chevrolet Pavão. - Boa, esta camioneta, antiga, mas boa. Onde é que eu estava? Ah, sim. Veio o delegado. Perguntei:"Senhor delegado, a que horas foi cometido o crime?" — "Mais ou menos às três da tarde, Cego" — respondeu ele. "Então" — disse eu. — "O senhor terá de procurar um Oldsmobile 1927. Este carro tem a surdina furada. Uma vela de ignição funciona mal. Na frente, viajava um homem muito gordo. Atrás, tenho certeza, mas iam talvez duas ou três pessoas." O delegado estava assombrado. "Como sabe de tudo isto, amigo?”- era só o que ele perguntava. Este que passou não foi um DKW? — Não, Cego. Foi um Volkswagen. Sim. O delegado estava assombrado. "Como sabe de tudo isto?" - "Ora, delegado" — respondi. — "Há anos que sento aqui à beira da estrada ouvindo automóveis passar. Conheço qualquer carro. Sem mais: quando o motor está mal, quando há muito peso na frente, quando há gente no banco de trás. Este carro passou para lá às quinze para as três; e voltou para a cidade 
às três e quinze." — "Como é que tu sabias das horas?" — perguntou o delegado. — "Ora, delegado" — respondi. — "Se há coisa que eu sei — além de reconhecer os carros pelo barulho do motor - é calcular as horas pela altura do sol." Mesmo duvidando, o delegado foi... Passou um Aero Willys? — Não, Cego. Foi um Chevrolet. — O delegado acabou achando o Oldsmobile 1927 com toda a turma dentro. Ficaram tão assombrados que se entregaram sem resistir. O delegado recuperou todo o dinheiro do fazendeiro, e a família me deu uma boa bolada de gratificação. Este que passou foi um Toyota? Não, Cego. Foi um Ford 1956. 